\title{
Correction to: Correlation of dosimetric factors with the development of symptomatic radiation pneumonitis in stereotactic body radiotherapy
}

\author{
Jeffrey M. Ryckman ${ }^{*}$, Michael Baine ${ }^{1}$, Joseph Carmicheal ${ }^{2}$, Ferdinand Osayande ${ }^{2}$, Richard Sleightholm², \\ Kaeli Samson ${ }^{3}$, Dandan Zheng ${ }^{1}$, Weining Zhen ${ }^{1}$, Chi Lin ${ }^{1}$ and Chi Zhang ${ }^{1}$
}

\section{Correction to: Radiat Oncol (2020) 15:33 \\ https://doi.org/10.1186/s13014-020-1479-6}

Following publication of the original article [1], we have been notified by the authors about the following corrections in the article.

The authors discovered errata concerning the definition of the V13.5 and V12.4 dose "limits" to the lung. Their work defined these volumes as the minimum volume of lung exposed to the corresponding doses instead of minimum volume of lung spared (MVLS) (Ritter, Matuszak et al. 2017). The section which reads incorrectly is in the Discussion section as follows:

"RTOG 0915 recommends limiting the volume of lung receiving 12.4 Gy $(\mathrm{V} 12.4)<1000 \mathrm{cc}$ while RTOG 0813 recommends limiting V13.5< $1000 \mathrm{cc}$. The median V12.4 was 223 cc (range $47-789$ cc) for asymptomatic patients and $372 \mathrm{cc}$ (range 311-932 cc) for patients with symptomatic RP. The median V13.5 was 195 cc (range $41-735 \mathrm{cc}$ ) for asymptomatic patients and $333 \mathrm{cc}$ (range $283-829 \mathrm{cc}$ ) for patients with symptomatic RP. These values are hypothesis generating, suggesting a lower threshold could be considered for these metrics as a novel

The original article can be found online at https://doi.org/10.1186/s13014020-1479-6.

*Correspondence: jeff.ryckman@unmc.edu

${ }^{1}$ Department of Radiation Oncology, University of Nebraska Medical Center, 505 S 45th Street, Omaha, NE 68106, USA

Full list of author information is available at the end of the article planning parameter to optimize treatment-associated patient morbidity further."

We have performed additional analysis of the MVLS from 12.4 Gy and MVLS from 13.5 Gy, switching these values for the previously reported values of V12.4 and V13.5 in Table 3 (see below). This section should read as:

"RTOG 0915 recommends the minimum volume of lung spared (MVLS) from 12.4 Gy to be at least $1000 \mathrm{cc}$ to minimize G3+ pneumonitis while RTOG 0813 recommends MVLS from 13.5 Gy to be at least $1000 \mathrm{cc}$ to minimize G3+ pneumonitis. RTOG 0813 also recommends MVLS from 12.5 Gy to be at least $1500 \mathrm{cc}$ to preserve basic lung function. The median MVLS from V12.4 was 3172 cc (range 968-6807 cc) for asymptomatic patients and $2131 \mathrm{cc}$ (range 1438-3592 cc) for patients with symptomatic RP. The median MVLS from V13.5 was 3196 cc (range 980-6829 cc) for asymptomatic patients and $2157 \mathrm{cc}$ (range 1452-3602 cc) for patients with symptomatic RP. MVLS for each parameter were the only two dosimetric parameters in Table 3 which did not reach statistical significance for symptomatic RP $(p=0.31)$. These findings are hypothesis generating, suggesting MVLS from 12.4 Gy and 13.5 Gy may not be as robust of parameters as previously believed."

The authors apologize for this error and are thankful the results did not change the significance of this work, as MVLS was statistically insignificant in regards to the development of symptomatic radiation pneumonitis.

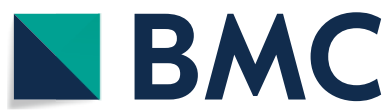

(c) The Author(s) 2021. Open Access This article is licensed under a Creative Commons Attribution 4.0 International License, which permits use, sharing, adaptation, distribution and reproduction in any medium or format, as long as you give appropriate credit to the original author(s) and the source, provide a link to the Creative Commons licence, and indicate if changes were made. The images or other third party material in this article are included in the article's Creative Commons licence, unless indicated otherwise in a credit line to the material. If material is not included in the article's Creative Commons licence and your intended use is not permitted by statutory regulation or exceeds the permitted use, you will need to obtain permission directly from the copyright holder. To view a copy of this licence, visit http://creativecommons.org/licenses/by/4.0/. The Creative Commons Public Domain Dedication waiver (http://creativeco mmons.org/publicdomain/zero/1.0/) applies to the data made available in this article, unless otherwise stated in a credit line to the data. 
Table 3 Dose volume histogram characteristics

\begin{tabular}{|c|c|c|c|}
\hline Characteristic & $\begin{array}{l}\text { No radiation } \\
\text { pneumonitis } \\
(n=85)\end{array}$ & $\begin{array}{l}\text { Symptomatic } \\
\text { radiation } \\
\text { pneumonitis }(n=8)\end{array}$ & $p$ value \\
\hline $\begin{array}{l}\text { Contralateral lung } \\
\text { V5, \% }\end{array}$ & & & 0.05 \\
\hline Median & $3.1 \%$ & $7.4 \%$ & \\
\hline Range & $0.0-33.6 \%$ & $4.2-53.4 \%$ & \\
\hline $\begin{array}{l}\text { Ipsilateral lung } \\
\text { v30,\% }\end{array}$ & & & 0.001 \\
\hline Median & $3.3 \%$ & $9.6 \%$ & \\
\hline Range & $0.8-11.6 \%$ & $6.5-12.8 \%$ & \\
\hline $\begin{array}{l}\text { Ipsilateral lung } \\
\text { v40,\% }\end{array}$ & & & 0.003 \\
\hline Median & $2.1 \%$ & $5.8 \%$ & \\
\hline Range & $0.5-8.1 \%$ & $3.6-8.8 \%$ & \\
\hline Total lung V5, \% & & & 0.001 \\
\hline Median & $14.7 \%$ & $29.1 \%$ & \\
\hline Range & $4.2-46.9 \%$ & $18.2-56.9 \%$ & \\
\hline Total lung V10, \% & & & 0.001 \\
\hline Median & $8.4 \%$ & $21.7 \%$ & \\
\hline Range & $2.2-34.6 \%$ & $10.8-38.4 \%$ & \\
\hline $\begin{array}{l}\text { MVLS from } 12.4 \mathrm{~Gy} \text {, } \\
\mathrm{cm}^{3}\end{array}$ & & & 0.31 \\
\hline Median & $3172 \mathrm{~cm}^{3}$ & $2132 \mathrm{~cm}^{3}$ & \\
\hline Range & $969-6807 \mathrm{~cm}^{3}$ & $1439-3592 \mathrm{~cm}^{3}$ & \\
\hline $\begin{array}{l}\text { MVLS from } 13.5 \mathrm{~Gy} \text {, } \\
\mathrm{cm}^{3}\end{array}$ & & & 0.31 \\
\hline Median & $3196 \mathrm{~cm}^{3}$ & $2157 \mathrm{~cm}^{3}$ & \\
\hline Range & $980-6829 \mathrm{~cm}^{3}$ & $1452-3603 \mathrm{~cm}^{3}$ & \\
\hline Total lung V15, \% & & & 0.001 \\
\hline Median & $5.4 \%$ & $13.2 \%$ & \\
\hline Range & $1.2-25.8 \%$ & $7.8-18.8 \%$ & \\
\hline Total lung V20, \% & & & 0.001 \\
\hline Median & $3.4 \%$ & $9.1 \%$ & \\
\hline Range & $0.8-19.4 \%$ & $5.3-12.8 \%$ & \\
\hline Total lung V25, \% & & & 0.001 \\
\hline Median & $2.4 \%$ & $6.7 \%$ & \\
\hline Range & $0.6-15.2 \%$ & $3.6-9.6 \%$ & \\
\hline Total lung V30, \% & & & 0.002 \\
\hline Median & $1.8 \%$ & $5.1 \%$ & \\
\hline Range & $0.5-12.1 \%$ & $2.4-7.4 \%$ & \\
\hline Total lung V40, \% & & & 0.003 \\
\hline Median & $1.1 \%$ & $3.3 \%$ & \\
\hline Range & $0.3-8.6 \%$ & $1.1-4.7 \%$ & \\
\hline
\end{tabular}

Abbreviations: Vdose is the percent of lung receiving greater than the "dose" (in Gy). Symptomatic Radiation Pneumonitis = RTOG G3 + or CTCAE G2 + RP. MVLS = Minimum Volume of Lung Spared

$p$ values from Wilcoxon Rank Sum tests, with all values Bonferroni adjusted. Bolded $p$ values indicate statistical significance

\section{Bibliography}

Ritter, T. A., et al. (2017). "Application of critical volume-dose constraints for stereotactic body radiation therapy in NRG radiation therapy trials." International Journal of Radiation Oncology Biology Physics 98(1): 34-36.

\section{Author details}

1 Department of Radiation Oncology, University of Nebraska Medical Center, 505 S 45th Street, Omaha, NE 68106, USA. ${ }^{2}$ College of Medicine, University of Nebraska Medical Center, Omaha, NE, USA. ${ }^{3}$ Department of Biostatistics, University of Nebraska Medical Center, Omaha, NE, USA.

Published online: 07 April 2021

\section{Reference}

1. Ryckman JM, et al. Correlation of dosimetric factors with the development of symptomatic radiation pneumonitis in stereotactic body radiotherapy. RadiatOncol. 2020;15:33. https://doi.org/10.1186/ s13014-020-1479-6.

\section{Publisher's Note}

Springer Nature remains neutral with regard to jurisdictional claims in published maps and institutional affiliations.

Ready to submit your research? Choose BMC and benefit from:

- fast, convenient online submission

- thorough peer review by experienced researchers in your field

- rapid publication on acceptance

- support for research data, including large and complex data types

- gold Open Access which fosters wider collaboration and increased citations

- maximum visibility for your research: over 100M website views per year

At BMC, research is always in progress.

Learn more biomedcentral.com/submissions 